\title{
Local Melting and Cracking during Friction Stir Spot Welding on Mg-Al binary Alloy $\dagger$
}

\author{
by S. Horie* , M. Yamamoto ${ }^{*}$, K. Shinozaki*, T. H. North ${ }^{* *}$, A. Gerlich ${ }^{* * *}$ and T. Shibayanagi ${ }^{* * * *}$
}

\begin{abstract}
Local melting and cracking are investigated during friction stir spot welding of binary $\mathrm{Mg}-\mathrm{Al}$ alloys containing from $3 \%$ to $23 \% \mathrm{Al}$ by using a combination of stir zone temperature, rotational torque and detailed metallographic. The stir zone temperatures during $\mathrm{Mg}-15 \% \mathrm{Al}$ and $\mathrm{Mg}-23 \% \mathrm{Al}$ alloys friction stir spot welding correspond with the $\left(\alpha-\mathrm{Mg}+\mathrm{Mg}_{17} \mathrm{Al}_{12}\right)$ eutectic temperature in the binary $\mathrm{Mg}$ - $\mathrm{Al}$ equilibrium phase diagram. The stir zone microstructures of friction stir spot welds in $\mathrm{Mg}-15 \% \mathrm{Al}$ and $\mathrm{Mg}-23 \% \mathrm{Al}$ alloys comprise fine equiaxed $\alpha$ phases and $\mathrm{Mg}_{17} \mathrm{Al}_{12}$. Narrow stir zones and lower rotational torques are observed when $\mathrm{Mg}-15 \% \mathrm{Al}$ and $\mathrm{Mg}-23 \% \mathrm{Al}$ alloys are spot welded since energy generation is diminished by tool slippage due to existing eutectic liquid at contact interface. These results support that local melting of the $\left(\alpha-\mathrm{Mg}+\mathrm{Mg}_{17} \mathrm{Al}_{12}\right)$ eutectic microstructure occurred at the contact interface between the tool surface and material when the stir zone temperature attained to the eutectic temperature in the binary $\mathrm{Mg}$-Al equilibrium phase diagram.

Liquation cracking is observed in the location beneath the tool shoulder in friction stir spot welds of Mg- $9 \% \mathrm{Al}$ alloy. The crack surface morphology is formed of dendrite shape. It is confirmed that the cracking occurred during Mg-9\%Al alloy friction stir spot welding is liquation cracking.
\end{abstract}

Key Words: FSSW, Cracking, Local melting, Mg alloy

\section{Introduction}

It is generally assumed that friction stir welding is a solid-state process which the temperature in the stir zone and TMAZ region is less than the solidus temperature of the alloy being fabricated. As a result, defect formation issues commonly associated with fusion welding are avoided. However, the validity of this solid-state assumption has been brought into question in recent research examining Mg-alloy and Al-alloy friction stir welding [1, 2] and friction stir spot welding [3-8]

Bendzsak and North $[3,4]$ suggested that the temperature in the stir zone attained to solidus temperature and local melting occurred at the contact interface during friction stir spot welding. They also proposed that tool slippage occurred at immediately adjacent to the periphery of the rotating tool when the local melting occurred and material viscosity remarkably decreased. Yamamoto et al $[5,6]$ recently found the evidence of cracking in the TMAZ regions of AZ91, AM60 and AZ31 friction stir spot welds and liquid penetration induced (LPI) cracking in the stir zone close to its extremity in AZ91 friction stir spot welds. They proposed that the cracking during $\mathrm{Mg}$ alloys friction stir spot welding occurred by $\left(\alpha-\mathrm{Mg}+\mathrm{Mg}_{17} \mathrm{Al}_{12}\right)$ eutectic local melting.

*Department of Mechanical System Engineering, Graduate School of Engineering, Hiroshima University

**Department of Materials Science and Engineering, University of Toronto

***Department of Chemical \& Engineering, University to Alberta

****Joint and Welding Research Institute, Osaka University
There are strong experimental supports, which the temperature in the stir zone is well corresponded with eutectic temperature indicated in $\mathrm{Mg}$ - $\mathrm{Al}$ equilibrium phase diagram [5, 6] and $\mathrm{Mg}_{17} \mathrm{Al}_{12}$ film outlining cracking at the location close to the extremity of the stir zone [5-8]. However, direct evidences are not still found, which prove that local melting and cracking induced by liquation during friction stir spot welding.

In this paper, local melting and cracking during friction stir spot welding are investigated in detail by using $\mathrm{Mg}$-Al alloys containing different $\mathrm{Al}$ contents. Local melting occurred when $\mathrm{Mg}-\mathrm{Al}$ alloys are heated up to each solidus temperatures by friction stir spot welding. Especially, much mount of eutectic liquid is formed when the binary alloys which have eutectic chemical composition are heated up to the eutectic temperature. In this case, heat generation is markedly diminished by tool slippage due to the eutectic melting formation at contact interface. With this in mind, a combination of the stir zone temperature, rotational torque and detailed metallographic are examined in present paper.

\section{Experimental procedure}

All friction stir spot welding test trials were carried out using $5 \mathrm{~mm}$ thick $\mathrm{x} 36 \mathrm{~mm}$ diameter sections of the $\mathrm{Mg}$-Al alloys containing $3 \% \mathrm{Al}, 9 \% \mathrm{Al}, 15 \% \mathrm{Al}$ and $23 \% \mathrm{Al}$ in mass $\%$, (call them $\mathrm{Mg}-3 \% \mathrm{Al}, \quad \mathrm{Mg}-9 \% \mathrm{Al}, \quad \mathrm{Mg}-15 \% \mathrm{Al}$ and $\mathrm{Mg}-23 \% \mathrm{Al}$ alloy respectively). Chemical compositions of binary materials used in this study are shown in Table 1 . Figure 1 shows $\mathrm{Mg}$-Al equilibrium phase diagram with solidus temperature of materials used. All Mg-Al alloys were produced by gravity-casting and the 
Table 1 Chemical composition of binary Mg-Al alloys.

\begin{tabular}{c|cccccc:|c}
\hline \multicolumn{1}{c|}{ material } & Al & Zn & Mn & Fe & Cu & Mg & Ts $\left({ }^{\circ} \mathrm{C}\right)$ \\
\hline \hline Mg-3\% Al & 3.05 & 0.00 & - & 0.00 & 0.11 & Bal. & 607 \\
Mg-9\% Al & 9.49 & 0.00 & 0.01 & - & - & Bal. & 503 \\
Mg-15\% Al & 15.38 & 0.00 & 0.01 & - & 0.25 & Bal. & $437\left(\mathrm{~T}_{\mathrm{E}}\right)$ \\
Mg-23\% Al & 23.71 & - & 0.02 & - & 0.01 & Bal. & $437\left(\mathrm{~T}_{\mathrm{E}}\right)$ \\
\hline
\end{tabular}

Table 2 Welding conditions for two types of controlled model FSSW machine.

\begin{tabular}{c|c|c}
\hline & Displacement control & Force control \\
\hline \hline Rotational speed (rpm) & 3000 & 3000 \\
Plunging rate (mm/s) & 2.5 & - \\
Axial Force (N) & - & 6000 \\
Dwell (Welding) time (s) & 4 & $0 \sim 4$ \\
\hline
\end{tabular}

casted samples were heat-treated at $420^{\circ} \mathrm{C} \times 24 \mathrm{~h}$ and cooled in the furnace to reduce compositional segregation in casting to provide a uniform structure. The microstructures of the $\mathrm{Mg}-\mathrm{Al}$ alloys prior to friction stir spot welding are shown in Fig.2. The microstructure of $\mathrm{Mg}-3 \% \mathrm{Al}$ alloy comprises $\alpha-\mathrm{Mg}$ and precipitated $\mathrm{Mg}_{17} \mathrm{Al}_{12}$ in grains. $\mathrm{Mg}-9 \% \mathrm{Al}, \mathrm{Mg}-15 \% \mathrm{Al}$ and $\mathrm{Mg}-23 \% \mathrm{Al}$ alloys are comprised $\alpha-\mathrm{Mg}$ with precipitated $\mathrm{Mg}_{17} \mathrm{Al}_{12}$ and eutectic $\mathrm{Mg}_{17} \mathrm{Al}_{12}$ on grain boundaries. $\mathrm{Mg}-9 \% \mathrm{Al}$ alloy has a slight amount of undissolved eutectic $\mathrm{Mg}_{17} \mathrm{Al}_{12}$ on grain boundaries.

Spot welding trials were carried out with the equipments using two different operating modes, namely:

i) Displacement-controlled mode: The rotating tool penetrated to a selected depth into the $\mathrm{Mg}-\mathrm{Al}$ alloy section during plunging term and was held there for a dwell time of 4 seconds. The tool rotational speed remained constant during the dwell period while the axial force and torque decreased.

ii) Force-controlled mode: In this case the tool rotational speed and axial force remained constant during the welding. The axial force of $6000 \mathrm{~N}$ and the armature current on the electric motor was taken as the measure of torque during friction stir spot welding.

The tool used in the present study had a shoulder diameter of $10 \mathrm{~mm}$, a pin diameter of $4 \mathrm{~mm}$, a pin length of $2.2 \mathrm{~mm}$ and a simple M4 threaded geometry. Welding parameters used in this study are shown in Table 2. Liquid formation and cracking is

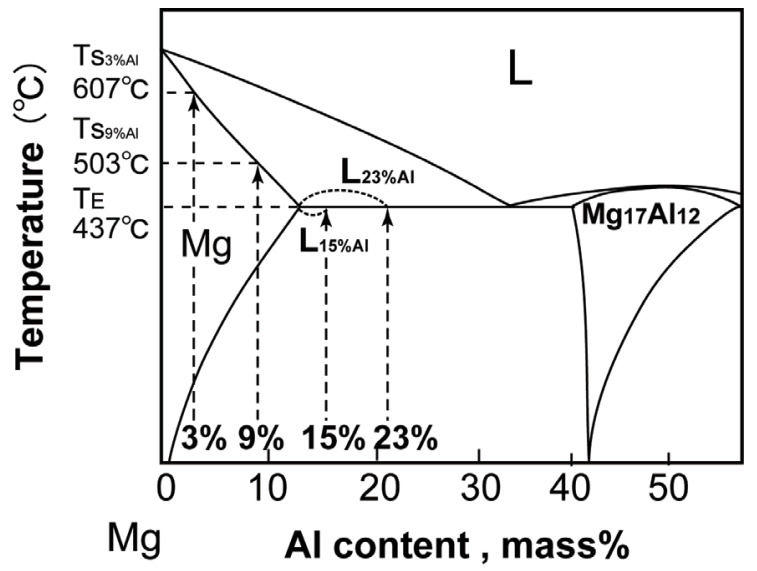

Fig. $1 \mathrm{Mg}$-Al equilibrium phase diagram. generally considered to be caused by high rotation speed as 3000rpm, however Gerlich et al proposed that cracking is also happened during AZ91 friction stir spot welding when low rotation speed is applied [9].

All stir zone temperature measurements were carried out with the friction stir spot welding equipment operating in the displacement-controlled mode. During temperature measurement the rotating pin was fully penetrated into the $\mathrm{Mg}$-alloy and a dwell time of 4 seconds was applied. The thermal cycle during spot welding was measured by embedding $0.25 \mathrm{~mm}$ diameter K-type thermocouples at the locations $0.2 \mathrm{~mm}$ from the tip of the rotating pin and $1.3 \mathrm{~mm}$ from the outer periphery of the tool shoulder. The detailed features of the temperature measurement set-up are provided elsewhere $[5,6]$.

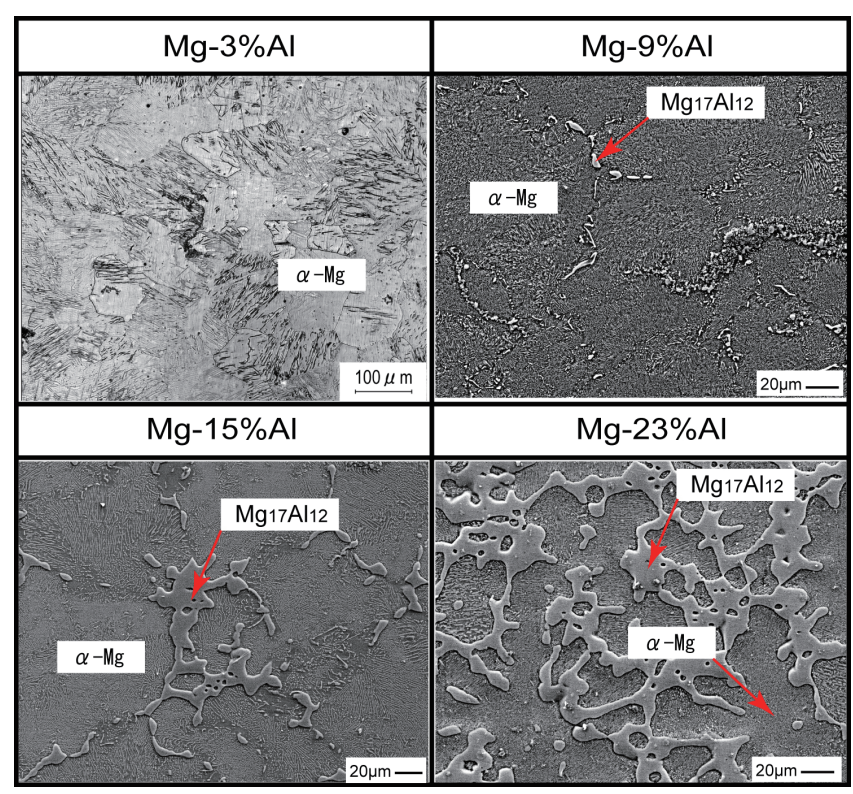

Fig. 2 Microstructures of Mg-Al alloy base materials containing different $\mathrm{Al}$ contents.

\section{Results and discussion}

\subsection{Local melting during friction stir spot welding}

Figure 3 shows the temperature cycles within the stir zone during friction stir spot welding. The stir zone temperatures approach to maximum at the beginning of the dwell period and indicate constant values during the dwell period. The highest stir zone temperatures well corresponds with each solidus temperatures, $0.93 \mathrm{~T}_{\mathrm{S}}\left(\mathrm{Mg}-3 \% \mathrm{Al}\right.$ alloy), $1.0 \mathrm{~T}_{\mathrm{S}}(\mathrm{Mg}-9 \% \mathrm{Al}$ alloy) and $0.97 \mathrm{~T}_{\mathrm{E}}\left(\mathrm{Mg}-15 \% \mathrm{Al}\right.$ alloy), where $\mathrm{T}_{\mathrm{S}}$ and $\mathrm{T}_{\mathrm{E}}$ indicate the solidus and the eutectic temperatures respectively, as shown in Fig.4.

Figure 5 shows appearances of cross sections of friction stir spot welding of different $\mathrm{Mg}-\mathrm{Al}$ alloys. It is clear that stir zones are almost never formed and plunging depths are shallow in both 


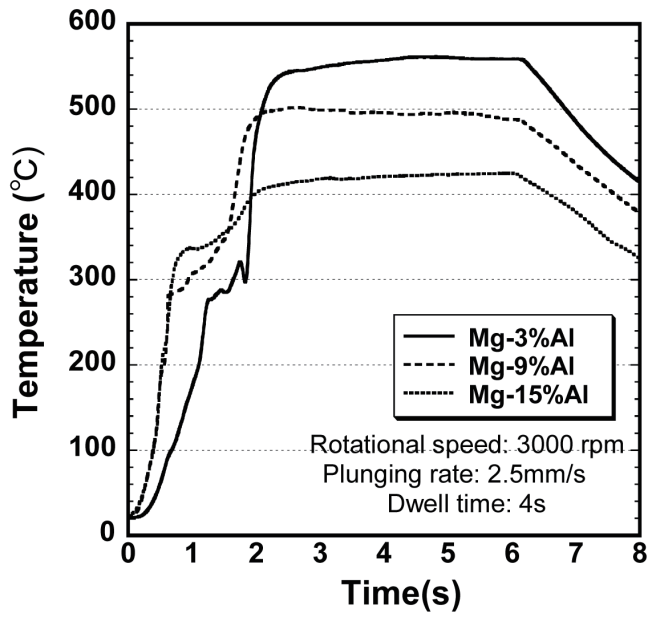

Fig. 3 Temperature cycle outputs measured at prove surface on Mg-Al binary alloys during FSSW.

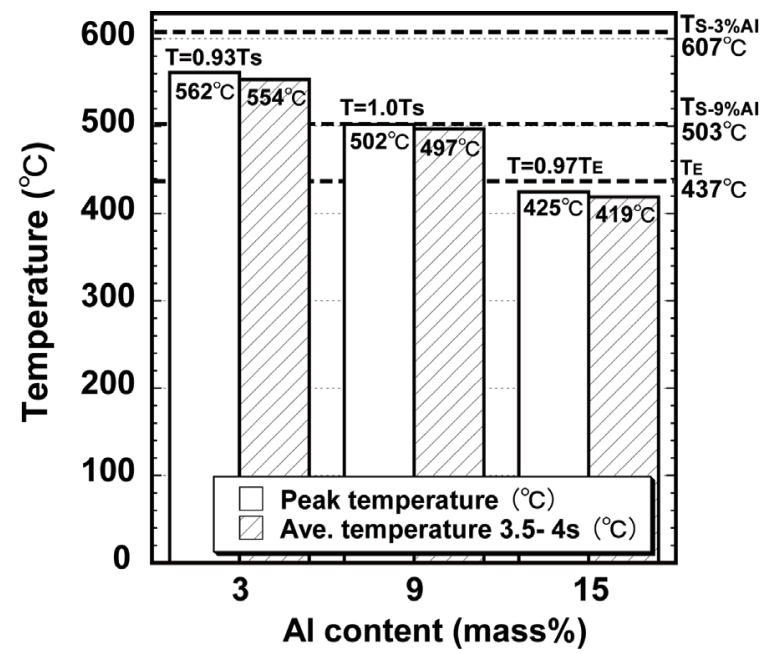

Fig. 4 Peak and average temperatures measured at prove surface during $\mathrm{Mg}-\mathrm{Al}$ alloys friction stir spot welding.

$\mathrm{Mg}-15 \% \mathrm{Al}$ and $\mathrm{Mg}-23 \% \mathrm{Al}$ alloys. The maximum widths of the stir zone and the plunging depth of tool shoulder from material surface in both $\mathrm{Mg}-15 \% \mathrm{Al}$ and $\mathrm{Mg}-23 \% \mathrm{Al}$ alloys are much smaller than $\mathrm{Mg}-3 \% \mathrm{Al}$ and $\mathrm{Mg}-9 \% \mathrm{Al}$ alloys as shown in Fig.6.

Figure 7 shows the microstructures in the stir zones of friction stir spot welding of each Mg-Al alloys. The stir zone microstructure comprises fine $\alpha-\mathrm{Mg}$ phase in $\mathrm{Mg}-3 \% \mathrm{Al}$ and $\mathrm{Mg}-9 \% \mathrm{Al}$ alloys. On the other hand, there are $\alpha-\mathrm{Mg}$ phase and blocky $\mathrm{Mg}_{17} \mathrm{Al}_{12}$ phase in $\mathrm{Mg}-15 \% \mathrm{Al}$ and $\mathrm{Mg}-23 \% \mathrm{Al}$ alloys.

Figure 8 shows the changes in armature current (torque) when each Mg-Al alloy containing different aluminum contents is welded using friction stir spot welding equipment operated in the force-controlled mode. The armature current (torque) values markedly decrease with increasing in Al contents.

All results seem to support the proposal that local melting occurred during fiction stir spot welding on Mg-Al alloys. The temperature in the stir zone is very close to the eutectic temperature and then indicates constant value during dwell period when Mg-15\%Al alloy is spot welded . As Fig.1 shows,

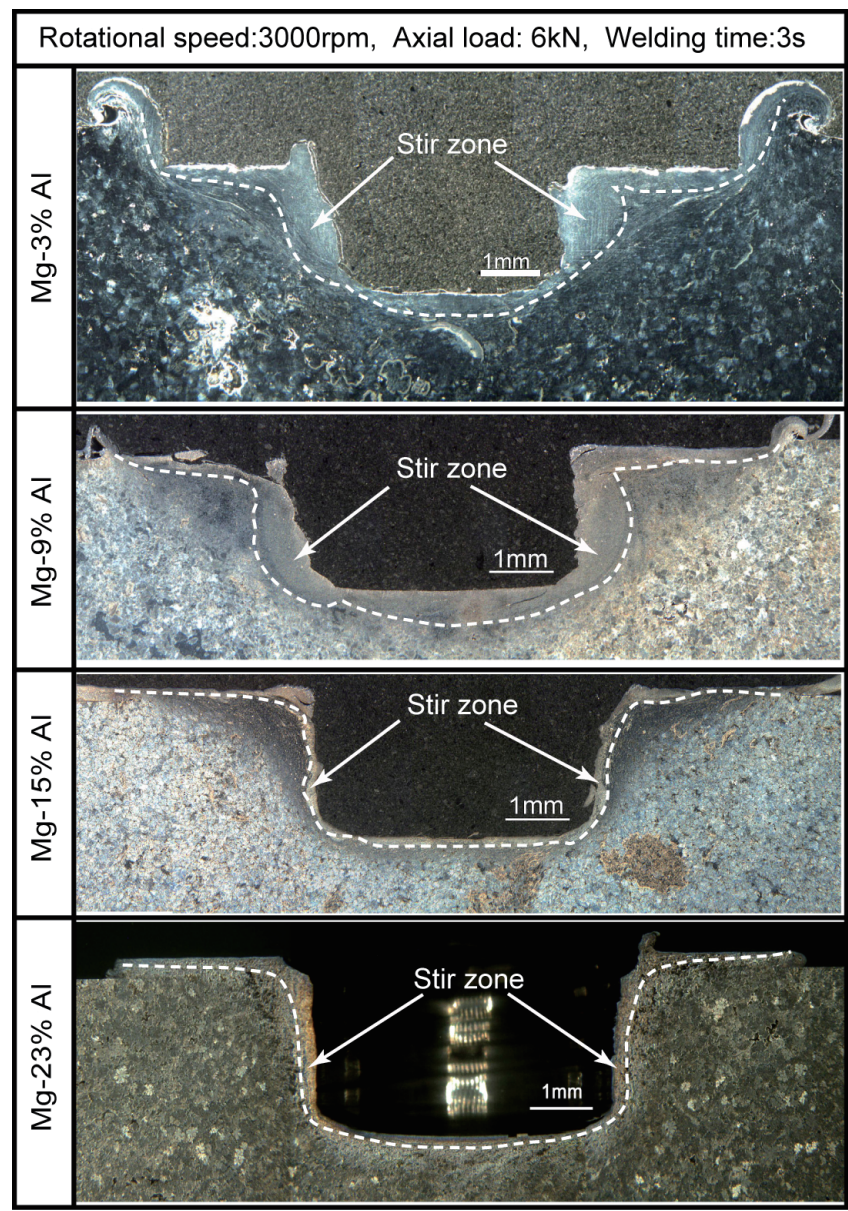

Fig. 5 Profiles of friction stir spot welds made in Mg-alloys containing different aluminum contents. The dotted line shows the extremity of the stir zone in each case.

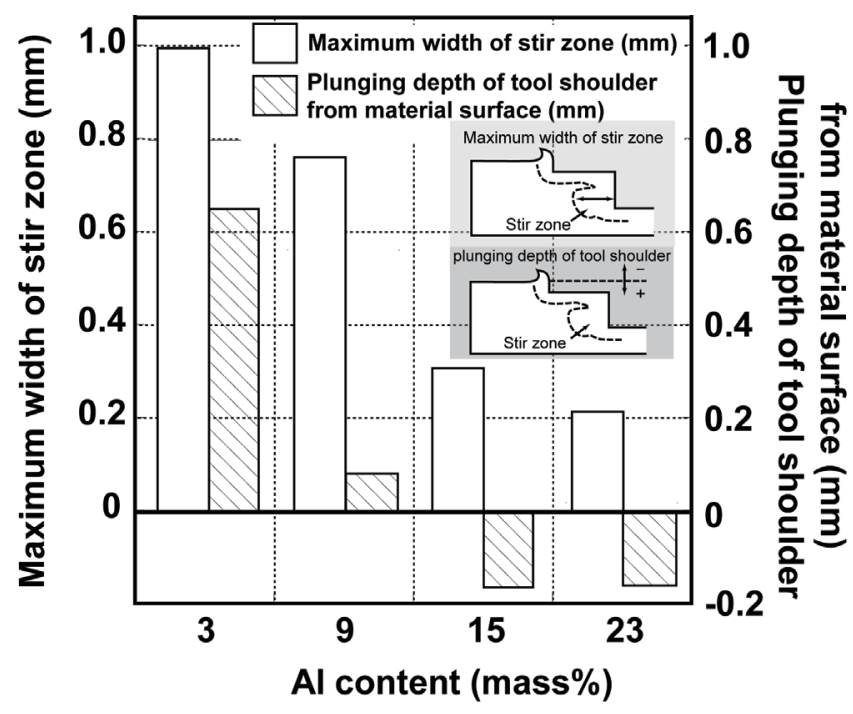

Fig. 6 Maximum width of stir zone and plunging depth of too shoulder of different $\mathrm{Mg}-\mathrm{Al}$ alloys spot welding.

much amount liquid occurred when the binary alloys, which has hypoeutectic composition like $\mathrm{Mg}-15 \% \mathrm{Al}$ and $\mathrm{Mg}-23 \% \mathrm{Al}$ are heated up to eutectic temperature. It is apparent that the eutectic microstructure exists in the stir zone after friction stir spot welding on $\mathrm{Mg}-15 \% \mathrm{Al}$ and $\mathrm{Mg}-23 \% \mathrm{Al}$ alloys, as shown in Fig.7. 


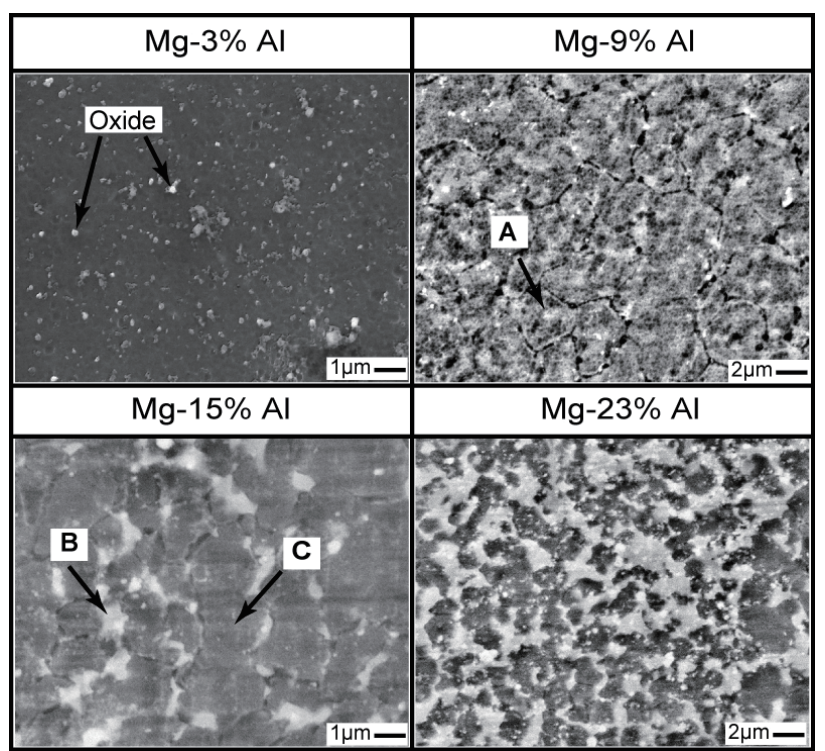

Fig. 7 Microstructures in stir zones.

EDX (A: 90.8wt\%-Mg， 9.2wt\%-Al. B: $79.2 \mathrm{wt} \%-\mathrm{Mg}$ 20.8wt\%-Al. C: $89.1 w t \%-M g, 10.9 w t \%-A l)$.

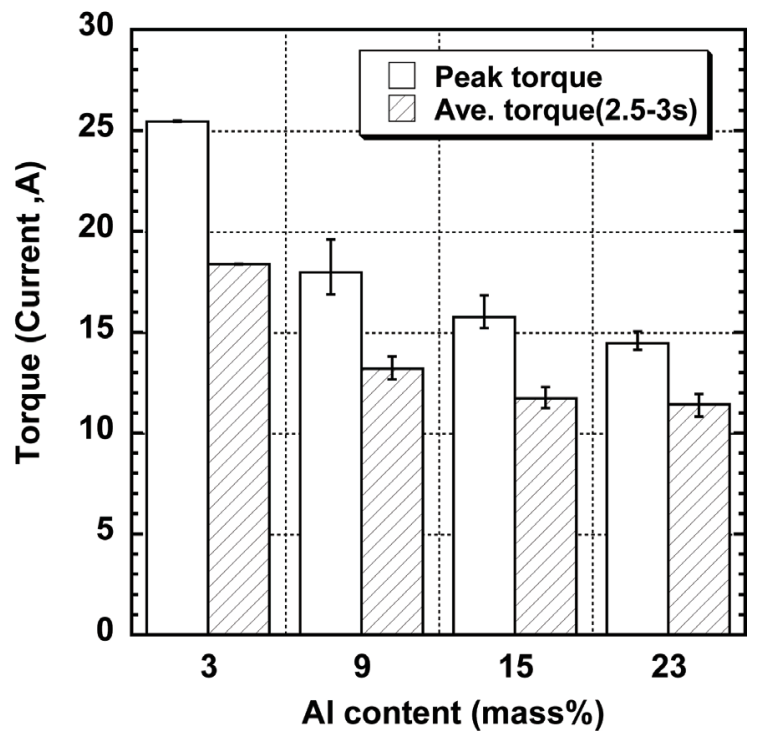

Fig. 8 Changes in measured armature current (torque) when $\mathrm{Mg}-\mathrm{Al}$ alloys containing different aluminum content are friction stir spot-welded with the FSSW machine of force-control mode

Therefore, these $\left(\alpha-\mathrm{Mg}+\mathrm{Mg}_{17} \mathrm{Al}_{12}\right)$ eutectic microstructures should be local melted during dwell period. Once local melting occurred at the location of contact interface between tool periphery and material surface, material viscosity is remarkably decreased and energy generation during friction stir spot welding is diminished by tool slippage due to eutectic melting liquid at the contact interface. Figure 8 indicates this tool slippage phenomenon very well. Since the armature current (torque) remarkably decrease with increasing $\mathrm{Al}$ content in $\mathrm{Mg}-\mathrm{Al}$ alloys. This tool slippage caused by eutectic melting formation at contact interface is the reason why the stir zones are not formed at all and the displacements of rotating tool from material surface during friction stir spot welding on $\mathrm{Mg}-15 \% \mathrm{Al}$ and $\mathrm{Mg}-23 \% \mathrm{Al}$ alloys are

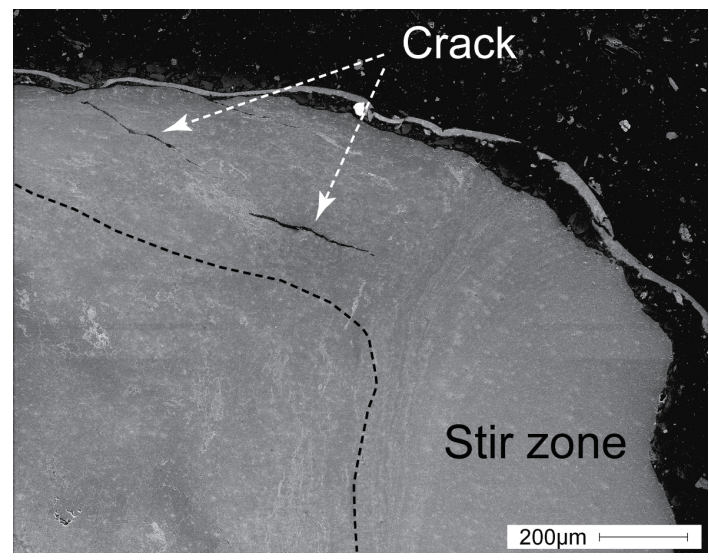

(a)

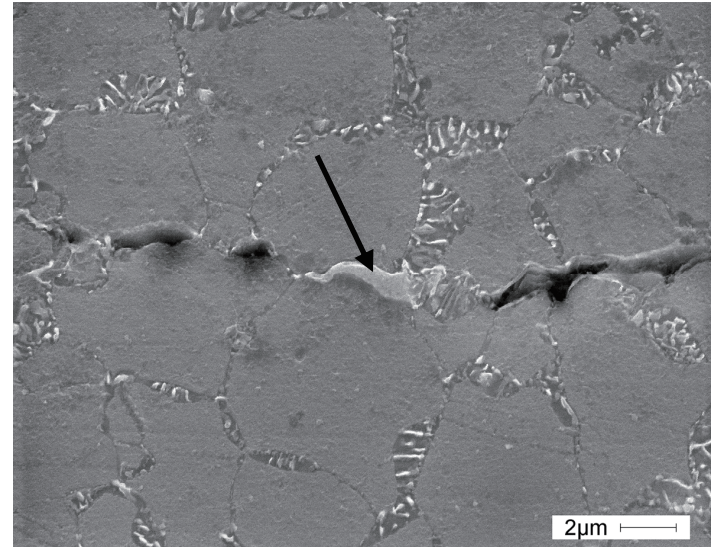

(b)

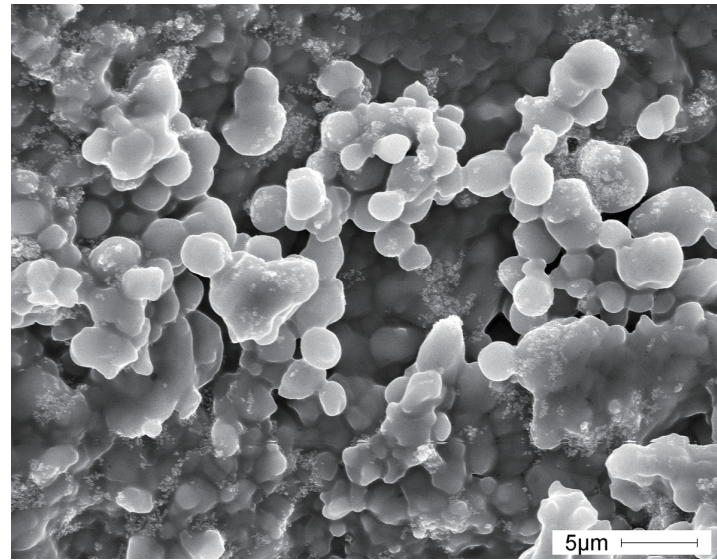

(c)

Fig. 9 Liquation cracking in the stir zone located in the location beneath the tool shoulder close to the top of the rotating pin. (a) Macro image (b) Cross section, EDX analysis at the location indicated arrow. $77.1 \mathrm{wt} \%-\mathrm{Mg}, 22.9 \mathrm{wt} \%-\mathrm{Al}$ (c) Crack surface.

much smaller than friction stir spot welding on $\mathrm{Mg}-3 \% \mathrm{Al}$ alloy despite of same welding condition.

\subsection{Liquation cracking during Mg-Al alloys friction stir spot welding}

Figure 9 shows the evidence of liquation cracking during Mg-9\%Al alloy friction stir spot welding. These cracks occurred 
at the location beneath the tool shoulder in the stir zone (see Fig.9 (a)). $\mathrm{Mg}_{17} \mathrm{Al}_{12}$ phases are found along crack (see Fig.9 (b)). Furthermore, the crack surface has the morphology as dendritic structure, which typically indicates that cracking caused by liquid formation during friction stir spot welding (see Fig.9(c)).

As mentioned earlier in Fig.2, although all base materials are heat-treated at $420^{\circ} \mathrm{C}$ for $24 \mathrm{~h}$, a slight amount of undissolved eutectic $\mathrm{Mg}_{17} \mathrm{Al}_{12}$ are still found in the base material of $\mathrm{Mg}-9 \% \mathrm{Al}$ alloy. These small particles should be local melted by $(\alpha-\mathrm{Mg}+$ $\mathrm{Mg}_{17} \mathrm{Al}_{12}$ ) eutectic reaction when the temperature in the stir zone reaches eutectic temperature. The temperature in the stir zone during dwell period is corresponded with solidus temperature of $\mathrm{Mg}-9 \% \mathrm{Al}$ alloy and is higher than the eutectic temperature during Mg-9\%Al alloy friction stir spot welding (See Fig.3 and Fig.4). Furthermore, it has been reported that the dissolution rate of melting eutectic film is so slow during AZ91 friction spot welding when the temperatures in the stir zone temperature are $437^{\circ} \mathrm{C}$ and $460^{\circ} \mathrm{C}[5,6]$. Thus this eutectic liquid film possibly remains during entire dwell period, and it causes liquation cracking when rotational torque and the displacement associated with tool withdrawal are applied.

\section{Conclusions}

Local melting and cracking has been investigated in detail during friction stir spot welding of $\mathrm{Mg}-\mathrm{Al}$ alloys containing 3\%, $9 \%, 15 \%$ and $23 \%$ aluminum contents. Main conclusions are as follows.

1. The temperatures in the stir zone of $\mathrm{Mg}-3 \% \mathrm{Al}$ and $\mathrm{Mg}-9 \% \mathrm{Al}$ alloys almost come up to each solidus temperatures and that of $\mathrm{Mg}-15 \% \mathrm{Al}$ alloy corresponded with the $\left(\alpha-\mathrm{Mg}+\mathrm{Mg}_{17} \mathrm{Al}_{12}\right)$ eutectic temperature

2. It is confirmed by using the combination of microscopic and torque measurement test that local melting and tool slippage clearly occurred at the contact interface between the tool surface and the base materials in $\mathrm{Mg}-15 \% \mathrm{Al}$ and $\mathrm{Mg}-23 \% \mathrm{Al}$ alloys, which has hypoeutectic composition. In other words, it is possible that $\left(\alpha-\mathrm{Mg}+\mathrm{Mg}_{17} \mathrm{Al}_{12}\right)$ eutectic local melting occurred when the base material which has eutectic microstructure like casted alloys are spot welded.

3. Liquation cracking occurred in the stir zone at the location beneath the tool shoulder during $\mathrm{Mg}-9 \% \mathrm{Al}$ alloy friction stir spot welding. It is confirmed that this liquation cracking is caused by $\left(\alpha-\mathrm{Mg}+\mathrm{Mg}_{17} \mathrm{Al}_{12}\right.$ ) eutectic local melting.

\section{Acknowledgements}

The authors wish to thank Kawasaki Heavy Industries, Ltd for support during this investigation

\section{References}

1) P.A. Colegrove, H.R. Shercliff, Experimental and numerical analysis of aluminium alloy 7075-T7351 friction stir welds, Science and Technology of Welding \& Joining, Volume 8, Number 5, October 2003, pp. 360-368(9).

2) K. Nakata, Cracking in dissimilar friction stir seam welds, to be presented 8th International Symposium of the Japan Welding Society, 16th/18th November 2008, Kyoto, Japan.

3) G.J. Bendzsak, T.H. North, and C. Smith, An experimentally validated3-D model for friction stir welding, Proc. 2nd Internat. Conf. On Friction Welding, TWI, Gothenburg, 26/28 June 2000.

4) T.H. North, G.J. Bendzsak, C.B. Smith, G.H. Luan, Numerical modeling and validation during friction stir welding of aluminum alloys, Proc. of the 7th Int. Symposium, JWS, Kobe, 2001.

5) M. Yamamoto, A. Gerlich, T.H. North and K. Shinozaki, Cracking in the stir zone of Mg-alloy friction stir spot welds, Journal of Material Science Vol.42,pp.7657-7666.

6) M. Yamamoto, A. Gerlich, T.H. North and K. Shinozaki, Mechanism of Cracking in AZ91 friction stir spot welds, Science and Technology of Welding and Joining Vol.12, (3):208-216.

7) Y. K. Yang, H. Dong, H. Cao, Y. A. Chang and S. Kou, Liquation of $\mathrm{Mg}$ alloys Friction Stir Spot Welding, Welding Journal, Vol. 87,July 2008, pp.167-177.

8) Y. K. Yang, H. Dong, and S. Kou, Liquation Tendency and Liquid-Film Formation in Friction Stir Spot Welding, Welding Journal, Vol. 87, August 2008, pp.202-211.

9) A. Gerlich, M. Yamamoto, T. Shibayanagi, T. H. North, Selection of Welding Parameter during Friction Stir Spot Welding, SAE, \# 2008-01-0146. 